Article

\title{
An Improvement on Selective Separation by Applying Ultrasound to Rougher and Re-Cleaner Stages of Copper Flotation
}

\author{
Ahmad Hassanzadeh ${ }^{1, *}$, Sayed Ali Sajjady ${ }^{2}$, Hamed Gholami ${ }^{3}$, Saeed Amini ${ }^{2}$ and \\ Safak Gökhan Özkan ${ }^{4}$ (D) \\ 1 Department of Processing, Helmholtz Institute Freiberg for Resource Technology, \\ Helmholtz-Zentrum Dresden-Rossendorf, Chemnitzer Straße 40, 09599 Freiberg, Germany \\ 2 Manufacturing Department, Faculty of Engineering, University of Kashan, Kashan 8731753153, Iran; \\ Alisajjady@grad.kashanu.ac.ir (S.A.S.); ammini.s@kashanu.ac.ir (S.A.) \\ 3 Department of Mining and Metallurgical Engineering, Amirkabir University of Technology, \\ Tehran 158754413, Iran; hamedgholami@aut.ac.ir \\ 4 Department of Robotics and Intelligent Systems, The Institute of the Graduate Studies in Science and \\ Engineering, Turkish-German University, 34820 Beykoz, Istanbul, Turkey; safak.ozkan@tau.edu.tr \\ * Correspondence: a.hassanzadeh@gmx.de or Hassanzadeh@itu.edu.tr
}

Received: 9 June 2020; Accepted: 8 July 2020; Published: 9 July 2020

check for updates

\begin{abstract}
It has been known that the power ultrasound is used as a pretreatment and rarely applied as a simultaneous method to improve grade and recovery during froth flotation processes. This work aimed at investigating the impact of simultaneously used ultrasonic waves under variant operating configurations on the flotation of representative porphyry copper ore during rougher and re-cleaner stages. For this purpose, four different operating outlines were examined as (I) conventional flotation, (II) homogenizer, (III) ultrasonic bath, and (IV) combination of a homogenizer and an ultrasonic bath. The ultrasonic vibration was generated by the homogenizer $(21 \mathrm{kHz}, 1 \mathrm{~kW})$ in the froth zone and ultrasonic bath $(35 \mathrm{kHz}, 0.3 \mathrm{~kW})$ in the bulk zone. The rougher and re-cleaner flotation experiments were conducted using Denver-type mechanically agitated cells with 4.2 and $1 \mathrm{~L}$ capacities, respectively. The results showed that using the homogenizer (at $0.4 \mathrm{~kW}$ ) slightly affected the selectivity separation index of chalcopyrite and pyrite, although it positively increased the grade of chalcopyrite from $21.5 \%$ to $25.7 \%$. The ultrasonic-assisted flotation experiments with the ultrasonic bath and its combination with the homogenizer $(0.4 \mathrm{~kW})$ (i.e., configurations III and IV) led to an increase of approximately $16.1 \%$ and $26.9 \%$ in the chalcopyrite selectivity index compared to the conventional flotation, respectively. At the cleaning stage, a lower grade of aluminum silicate-based minerals was obtained desirably in every ultrasonic-treated configuration, which was supported with the water recoveries. Finally, applying the homogenizer and its combination with the ultrasonic bath were recommended for re-cleaner and rougher stages, respectively. Further fundamental and practical knowledge gaps required to be studied were highlighted.
\end{abstract}

Keywords: ultrasonic pretreatment; simultaneous ultrasonic treatment; copper flotation; homogenizer; rougher and re-cleaner stages

\section{Introduction}

Historically, the basis for the present-day generation of ultrasound was established in the 1880s with the discovery of the piezoelectric effect by the Curies [1]. Later in the 1990s, several works pointed out its applications in materials science [2,3]. Ultrasound causes high-energy chemistry through the process of acoustic cavitation, which means the formation, growth, and implosive collapse of bubbles 
in a liquid. Near an extended solid surface, cavity collapse is non-spherical and drives high-speed jets of liquid into the surface. This process can produce newly exposed and highly heated surfaces [2]. In heterogeneous solid-liquid reactions, ultrasound increases the reactivity of metal powders by as much as 100,000-fold [3]. Numerous studies have shown the application of ultrasonic frequencies (>20 kHz), known as ultra-sonication, to mineral beneficiation particularly in the interface science [4], biochemistry [5], flotation [6-9], and hydrometallurgy [10,11].

Flotation is one of the most complex but extensively applicable techniques used for separating primary and secondary raw materials in various industries [12]. It is a physicochemical-based process, which utilizes the difference in surface properties of the valuable and gangue minerals. The theoretical and practical aspects of flotation are complex involving three phases (i.e., solid (particles), liquid (water), and gas (air bubbles) with many subprocesses and interactions [13,14]. A little improvement in preconditioning steps may lead to remarkable changes in downstream processes, particularly selective separations. So far, the only pretreatment methods before floating are desliming [15], attritioning [16], sulphidization [17], and ultrasonic- [18] and microwave-assisted [19-21] processes. The most commonly used one is ultrasonic radiation [22] utilized for emulsifying flotation reagents [23] and removing surface coatings of clay and iron oxides from mineral surfaces [24].

Unlike other methods that require a special attribute of the system being activated in order to produce an effect, such as the use of microwaves (dipolar species), electrochemistry (conducting medium), or photochemistry (the presence of a chromophore), ultrasound requires only the presence of a liquid to transmit its energy [22]. Moreover, using this technique does not cause any chemical change in the material. In ultrasonic processes, frequencies of $10^{4}$ to $10^{5} \mathrm{~Hz}$ are used, which is substantially lower than the frequency range of $10^{8}$ to $10^{10} \mathrm{~Hz}$, where vibrational waves can affect the irregular lines of the crystal lattice [25]. In flotation processes, acoustic cavitation cleans particle surfaces, minimizes slime coatings, and enhances surfactant adsorptions, in particular, collectors. Acoustic cavitation in a multi-phase system leads to the generation of submicron (nano)-sized bubbles on particle surfaces, which enhances the particle-bubble contact angle. Sound irradiation may change the $\mathrm{pH}$ value, surface tension, and oxidation-reduction potential of flotation pulp with a certain variation in local temperature, dissolved oxygen, conductivity, and pressure [26,27].

Aside from many studies focusing on the positive impact of the ultrasound on coal flotation [28-32], few works have reported its role in copper beneficiation processes. In this context, Videla et al. [33] applied ultrasound treatment using nine ultrasonic transducers (Clangsonic 2045-68LB P8) at different configurations (i.e., ultrasound conditioning, ultrasound flotation, and flotation and conditioning with ultrasound) on El Teniente plant's tailings to enhance copper recovery. It was indicated that when ultrasound was applied during conditioning and flotation (8 L mechanical Denver cell), copper recovery increased up to $3.5 \%$ by cleaning particle surfaces, minimizing slime coatings, and facilitating the action of the reagents. Cilek and Ozgen [34] located an ultrasonic probe (Bandelin Sonoplus HD 2200, $20 \mathrm{kHz}$, $0.2 \mathrm{~kW}$ ) into the froth phase of a $2 \mathrm{~L}$ Denver laboratory flotation cell. The experimental results showed that the pulp recovery of a chalcopyrite-based ore sample was considerably improved specifically at intermediate- and low-level froth depths. However, the froth recovery reduced owing to an increase in bubble coalescence and a reduction of available bubble surface area. Hernández et al. [35] comparatively studied the impact of high-intensity conditioning and ultrasonic radiation on the floatability of a finely ground Chilean copper ore (El Teniente, Codelco) using a 2.7 L Denver mechanical cell. It was disclosed that the ultrasonic treatment could provide a promising improvement in copper recovery with $1 / 3$ energy consumption compared to the high-intensity conditioning. Aldrich and Feng [22] applied a $5 \mathrm{~L}$ ultrasonic bath $\left(20 \mathrm{kHz}\right.$ and specific power of $\left.2 \mathrm{~W} / \mathrm{cm}^{2}\right)$ to a base metal sulphide (Merensky ore samples, South Africa) by containing the noble metals and liberated platinum group minerals. They found that after ultrasonic excitation, the floatability of the sulphides improved significantly, and the silicates were also depressed to some extent. 
Other works related to the current subject are only limited to colemanite [36], ilmenite [37], magnesite [38], phosphate [39], calcite, barite, and quartz [35,40], copper ore [34], copper tailing [33], arsenopyrite [41], quartz [42-44], pyrite [27,45], galena [46,47], and feldspar [48] in the literature. Nevertheless, most of those studies did not cover the entire possible configurations of homogenizer and ultrasonic bath during flotation processes. Another important fact that has not been adequately addressed in the previous studies is the impact of ultrasound on different stages of the flotation process. Most of the research works have reported the impact of the ultrasonic treatment only on the rougher flotation stage $[33,49]$ without considering it further in the scavenger, cleaner, and re-cleaner stages. Although the beneficial effect of ultrasonication either as a pretreatment or during the flotation process is well recognized on the laboratory scale, its application on an industrial scale remains limited.

In this paper, four different operating configurations were examined in a copper porphyry ore flotation, including (I) conventional flotation, (II) homogenizer, (III) ultrasonic bath, and (IV) combination of a homogenizer and an ultrasonic bath. Furthermore, the effect of acoustic waves was initially explored in both the froth and pulp flotation zones at the rougher and re-cleaner stages.

\section{Materials and Methods}

\subsection{Sampling and Preparations}

The initial representative bulk ore samples were taken from the ball mill's feed $\left(\mathrm{F}_{80}=15 \mathrm{~mm}\right)$ from the Sarcheshmeh porphyry copper concentration plant located in Rafsanajan, Iran. This plant is one of the largest copper concentrators worldwide producing 50,000 tons of copper concentrate per month with an average grade of $28-32 \% \mathrm{Cu}$ in the final re-cleaner flotation [50,51]. Annually, 3500-4000 tons of molybdenite concentrate is produced as a by-product with a grade between 53-55\% Mo [52]. Detailed information about the operating properties of the grinding and flotation circuits is given elsewhere [53]. The sampling process was carried out during a day after ensuring that the circuit was operating under a steady-state condition. The present samples were taken from the conveyor belt after shutting down the primary ball mill.

The samples were prepared after two stages of laboratory comminution including crushing in a jaw crusher (Retsch, BB100, Haan, Germany) and grinding by a standard Bond ball mill to break the particle sizes down to $<2 \mathrm{~mm}$ and $<0.074 \mathrm{~mm}$, respectively. The samples were homogenized and subsequently split by means of cones and riffles. To keep the effect of particle size distribution in the flotation experiments constant, the grinding time was selected in a way to reach $\mathrm{P}_{80}=74 \mu \mathrm{m}$ and $44 \mu \mathrm{m}$ at the rougher and re-cleaner stages, respectively. These $\mathrm{P}_{80}$ values are the standard and optimum particle sizes acquired on the industrial scale to achieve a maximum liberation degree of chalcopyrite (approximately $75-80 \%$ ) as the predominant copper-bearing mineral in the ore. The role of particle size on the laboratory and industrial scales has been investigated and reported by authors in previous works [54,55]. Figure 1 displays the sample's particle size distributions measured by a dry sieving analysis, which was conducted in a dry environment choosing the US sieve series and Taylor mesh sizes. 


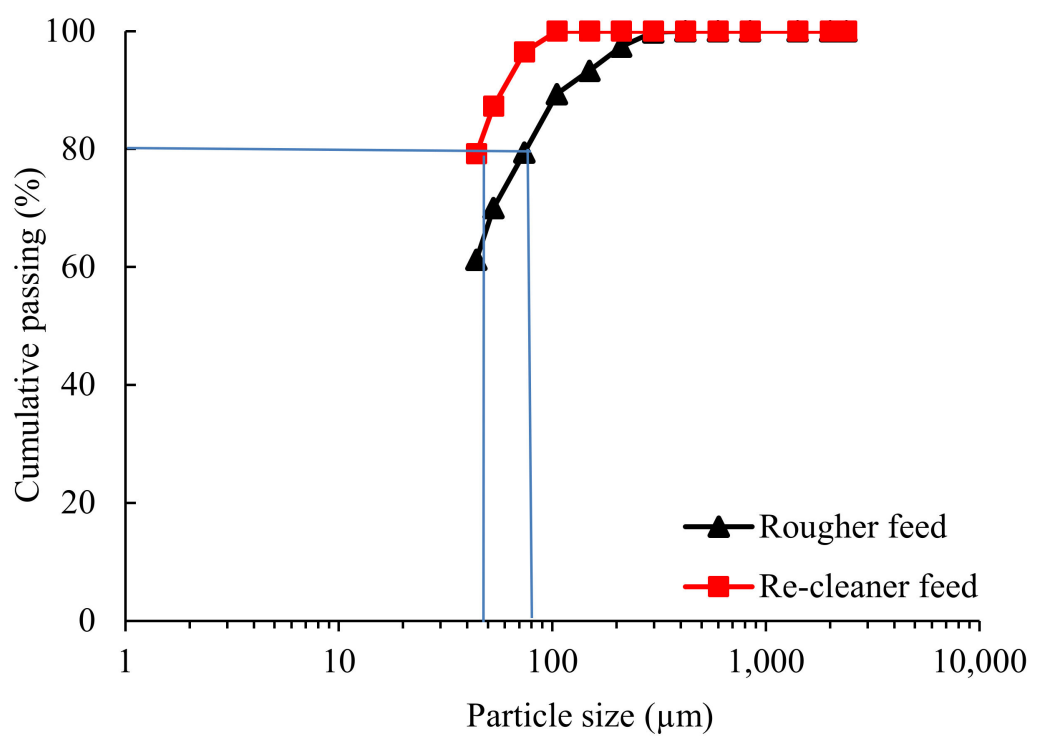

Figure 1. Particle size distribution of the samples fed to the laboratory flotation cells.

\subsection{Chemical Characterization}

Chemical analyses were carried out using atomic absorption spectroscopy (Varian, AA 220FS, California, United States) and X-ray fluorescence (Philips, 1480-PW model). Mineralogical analyses for the identification of mineral mode were performed using the spot counting method via optical microscopy (Leica, DM-LP, Wetzlar, Germany) and an in-house developed software at the central laboratories of the Sarcheshmeh copper complex. Detailed information regarding the sample preparation procedures for these analyses can be found elsewhere [56]. Table 1 presents the chemical composition and Table 2 shows the mineralogical analysis of the sample. As shown, the predominant copper-bearing mineral of the ore sample is chalcopyrite, and the main iron-bearing minerals are pyrite and chalcopyrite. Hence, chalcopyrite can be the representative of $\mathrm{Cu}$ recovery, and after subtracting its iron content in the concentrate, the pyrite recovery is considered as the recovery of Fe.

Table 1. Chemical composition (wt.\%) of the studied sample.

\begin{tabular}{llllllllllllll}
\hline $\mathrm{Cu}$ & $\mathrm{Fe}$ & $\mathrm{CuO}$ & $\mathrm{Mo}$ & $\mathrm{Al}_{2} \mathrm{O}_{3}$ & $\mathrm{~K}_{2} \mathrm{O}$ & $\mathrm{SiO}_{2}$ & $\mathrm{~S}$ & $\mathbf{M g O}$ & $\mathrm{K}_{2} \mathrm{O}$ & $\mathrm{TiO}_{2}$ & $\mathrm{CaO}$ & $\mathbf{P}_{2} \mathrm{O}_{5}$ & LOI \\
\hline 0.75 & 5.45 & 0.04 & 0.03 & 15.41 & 5.84 & 56.35 & 3.50 & 3.82 & 5.84 & 0.99 & 0.89 & 0.27 & 0.82 \\
\hline
\end{tabular}

Table 2. Mineralogical composition (wt.\%) of the studied sample.

\begin{tabular}{cccc}
\hline Mineral & Content (wt.\%) & Mineral & Content (wt.\%) \\
\hline Chalcopyrite $\left(\mathrm{CuFeS}_{2}\right)$ & 1.31 & Pyrite $\left(\mathrm{FeS}_{2}\right)$ & 8.29 \\
Hematite $\left(\mathrm{Fe}_{2} \mathrm{O}_{3}\right)$ & 0.38 & Molybdenite $\left(\mathrm{MoS}_{2}\right)$ & 0.05 \\
Covellite $(\mathrm{CuS})$ & 0.01 & Sphalerite $(\mathrm{ZnS})$ & 0.09 \\
Chalcosite $\left(\mathrm{Cu}_{2} \mathrm{~S}\right)$ & 0.02 & Bornite $\left(\mathrm{Cu}_{5} \mathrm{FeS}_{4}\right)$ & 0.061 \\
Quartz $\left(\mathrm{SiO}_{2}\right)$ & 17.41 & Muscovite $\left(\mathrm{KAl}_{2}(\mathrm{OH}, \mathrm{F})_{2} \mathrm{AlSi}_{3} \mathrm{O}_{10}\right)$ & 25.50 \\
Calcite $\left(\mathrm{CaCO}_{3}\right)$ & 6.98 & Illite $\left(\left(\mathrm{K}, \mathrm{H}_{3} \mathrm{O}\right)(\mathrm{Al}, \mathrm{Mg}, \mathrm{Fe})_{2}\left(\mathrm{Si}_{1}, \mathrm{Al}\right)_{4} \mathrm{O}\right)$ & 27.80 \\
Albite $\left(\mathrm{NaAlSi}_{3} \mathrm{O}_{8}\right)$ & 6.10 & Clinochlore $\left(\mathrm{Mg}_{5} \mathrm{Al}\left(\mathrm{AlSi}_{3} \mathrm{O}_{10}\right)(\mathrm{OH})_{8}\right)$ & 6.00 \\
\hline
\end{tabular}

\subsection{Contact Angle Measurement}

To understand the impact of ultrasonication on mineral hydrophobicity and simulate the particle surface changes under the given operating condition of ultrasonic bath in the flotation experiments, contact angle measurements were performed. A thin-layer section of the mineral of interest (chalcopyrite) was prepared for the contact angle measurements. An optical contact angle measuring system (OCA 50 series, DataPhysics, Filderstadt, Germany) with an electronic dosing 
function was utilized for determining mineral wettability characteristics using the captive bubble method. To reach a reasonable reproducibility, wettability tests were repeated four times, and error propagation was calculated at $95 \%$ confidence level. Prior to measurements, the mineral surface was polished with a DiaPro $1 / 4 \mu \mathrm{m}$ diamond suspension on a DP-Nap polishing cloth for $30 \mathrm{~s}$. Subsequently, the sample was cleaned in a beaker with deionized water in an ultrasonic bath for 5 min. Afterward, it was rinsed with HPLC-grade ethanol and swiped with a lint-free cloth. To wipe out any potential contaminations on the mineral surface, it was washed three times with Milli-Q water and blow-dried with pressurized air. The Young-Laplace equation was fitted to calculate the contact angle. To keep the effect of water composition in the measurements constant, a large volume of deionized water was stored and used for all the experiments, while its temperature and $\mathrm{pH}$ level were monitored continuously.

\subsection{Flotation Experiments}

Rougher flotation tests were performed using a mechanically agitated Denver flotation machine with an impeller speed of $1400 \mathrm{rpm}$ in a $4.2 \mathrm{~L}$ cell following the standard flotation procedure in the Sarcheshmeh beneficiation plant [57-59]. Initially, the pulp with $28 \%$ solids was entered to the cell, and then the $\mathrm{pH}$ was adjusted at 11.8 with lime $\left(\mathrm{Ca}(\mathrm{OH})_{2}\right)$ and conditioned for $3 \mathrm{~min}$. After this period, the collector and frother reagents were added with corresponding conditioning times of 1 and $2 \mathrm{~min}$. At the rougher stage and after the aeration, cumulative timed concentrates were collected for $8 \mathrm{~min}$, while the froth was scraped every $10 \mathrm{~s}$.

The re-cleaner flotation tests were undertaken in a $1 \mathrm{~L}$ Denver flotation cell with an agitating rate of $900 \mathrm{rpm}$ and 15\% solid content, and incremental froth was collected for 4 min accumulatively. To do this, the rougher concentrate was firstly re-ground to reach a product size of $\mathrm{P}_{80}=44 \mu \mathrm{m}$. Thereafter, the product was poured into a $1 \mathrm{~L}$ flotation cell for preparation of the cleaner experiment. At this stage, $30 \%$ of the collector dosage used in the rougher stage was added and the slurry conditioned for $2 \mathrm{~min}$ at a $\mathrm{pH}$ of 12. The airflow was turned on and the froth collection was started for $3 \mathrm{~min}$. Eventually, the concentrate of the cleaning stage was poured into a $1 \mathrm{~L}$ vessel for the re-cleaner experiment. The concentrates and tailings were then filtered, dried, weighed, and assayed. The grade of copper and iron in each section was measured using the $\mathrm{X}$-ray fluorescence technique.

The reagent types and dosages were selected according to the standard conditions of the Sarcheshmeh copper processing plant [60]. A mixture of sodium isopropyl xanthate $\left(\mathrm{Z11}, \mathrm{C}_{4} \mathrm{H}_{7} \mathrm{NaOS}_{2}\right.$, $15 \mathrm{~g} / \mathrm{t}$ ) and butyl sodium dithiophosphate (Flomin $7240, \mathrm{Na}_{3} \mathrm{PS}_{2} \mathrm{O}_{2}, 25 \mathrm{~g} / \mathrm{t}$ ) was used as collectors, whereas methyl isobutyl carbinol (MIBC, $\left.\left(\mathrm{CH}_{3}\right)_{2} \mathrm{CHCH}_{2} \mathrm{CH}(\mathrm{OH}) \mathrm{CH}_{3}, 15 \mathrm{~g} / \mathrm{t}\right)$ and polypropylene glycol (F742, $\mathrm{H}\left[\mathrm{OCH}\left(\mathrm{CH}_{3}\right) \mathrm{CH}_{2}\right]_{n} \mathrm{OH}, 15 \mathrm{~g} / \mathrm{t}$ ) were employed as frothers.

To evaluate the performance of flotation tests and the effect of ultrasonic waves, chalcopyrite and pyrite recoveries were calculated using the mass balance method based on Equation (1):

$$
R=\frac{C c}{F f} \times 100
$$

where $R(\%)$ is recovery, $C(\mathrm{~g})$ is the dry weight of the concentrate, $c$ denotes the grade of concentrate, and $F(\mathrm{~g})$ and $f$ represent the dry weight of the feed and its grade, respectively.

Furthermore, Gaudin's selectivity index (SI) [61] was selected as the key indicator for evaluating the metallurgical efficiency of the separation, which has been confirmed as a useful estimator in froth flotation processes [62,63].

Gaudin (1939) proposed the SI as the convenient measure of two-product separation. The selectivity index is a geometrical mean of the relative rejections and relative recoveries of two components (minerals, metals, or groups of minerals or metals) [64]. 
Chalcopyrite mass was calculated based on its content (copper grade) and mass recovery. The amount of chalcopyrite was measured from the copper content by the following equation:

$$
C_{\text {chalcopyrite }}=\frac{C_{C u}^{\text {Conc }}}{C_{C u}^{\max }} \times 100
$$

To calculate the selectivity index of valuable chalcopyrite from gangue minerals (i.e., pyrite, silicates, and the rest of the minerals), the SI (Equation (3)) was defined as a comprehensive indicator by considering copper content in the feed and concentrate:

$$
S I=\sqrt{\frac{R_{m} \times\left(100-R_{g}\right)}{\left(100-R_{m}\right) \times R_{g}}}
$$

where $R_{m}(\%)$ is the chalcopyrite recovery and $R_{g}(\%)$ denotes the gangue recovery in the concentrate, which was formulated based on the copper contents in the feed and concentrate as Equation (4):

$$
R_{g}=\frac{m_{g}^{\text {conc }}}{m_{g}^{f}}=\frac{1-\frac{C_{C u}^{C o n c}}{C_{C u}^{\max }}}{1-\frac{C_{C u}^{f e e d}}{C_{C u}^{\max }}} \times R_{m}
$$

where $R_{m}$ is the mass recovery and $C_{C u}^{C o n c}$ and $C_{C u}^{f e e d}$ represent copper grades in the concentrate and feed, respectively.

\subsection{Ultrasonic Treatment}

A homogenizer (CS-300-35 model, Behin Tamin Ahura Co., Isfahan, Iran) and an ultrasonic bath (BTA-20 model, Isfahan, Iran) were used in the ultrasonic treatments. The homogenizer was operated at $21 \mathrm{kHz}$ frequency, $1 \mathrm{~kW}$ total power of a generator (MPI model, Le Locle, Switzerland), and a maximum oscillatory amplitude of $40 \mu \mathrm{m}$. In order to apply vibration to the bubbles in the froth zone, the homogenizer's horn was placed at the boundary of the pulp and froth phases. The homogenizer was operated at two power levels, namely low $(0.4 \mathrm{~kW})$ and high $(0.8 \mathrm{~kW})$, to investigate its power impact on the overall performance of the flotation process.

The ultrasonic bath was positioned at the bottom of the flotation cell. It ran at $35 \mathrm{kHz}$ resonance frequency, $0.3 \mathrm{~kW}$ power, and a maximum oscillating of $10 \mu \mathrm{m}$. The variability of the liquid temperature in the presence and absence of the ultrasonic bath was determined to be $27.3 \pm 1.2^{\circ} \mathrm{C}$ and $19.2 \pm 1.0^{\circ} \mathrm{C}$, respectively. Since the ultrasound loses energy during propagation in water [65], solid concentration was kept constant for all flotation experiments. Figure 2 displays the schematic view of the experimental settings for this study. The simultaneous ultrasonic and flotation tests were conducted at different configurations as (I) conventional flotation (CF), (II) homogenizer (H), (III) ultrasonic bath (UB), and (IV) combination of a homogenizer and an ultrasonic bath (HUB) (Table 3).

Table 3. Description of various experimental configurations applied during simultaneous flotation tests with the ultrasonic treatment.

\begin{tabular}{cccc}
\hline Identification & Flotation (Yes/No) & Homogenizer (Yes/No) & Ultrasonic Bath (Yes/No) \\
\hline CF & Yes & No & No \\
H $0.8 \mathrm{~kW}$ & Yes & Yes & No \\
H $0.4 \mathrm{~kW}$ & Yes & Yes & No \\
UB & Yes & No & Yes \\
HUB $0.8 \mathrm{~kW}$ & Yes & Yes & Yes \\
HUB $0.4 \mathrm{~kW}$ & Yes & Yes & Yes \\
\hline
\end{tabular}




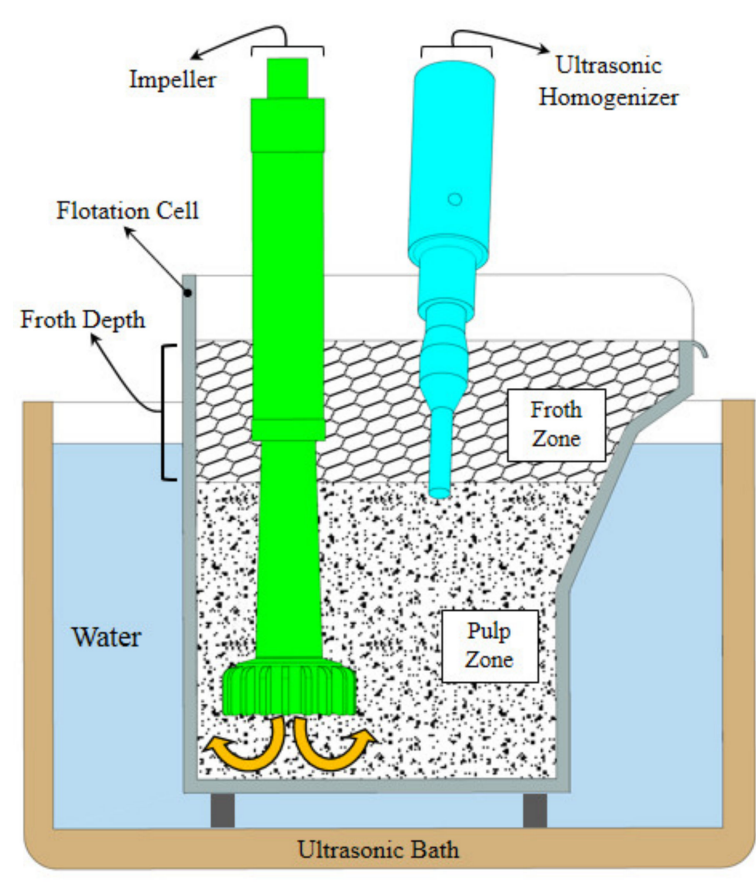

(a)

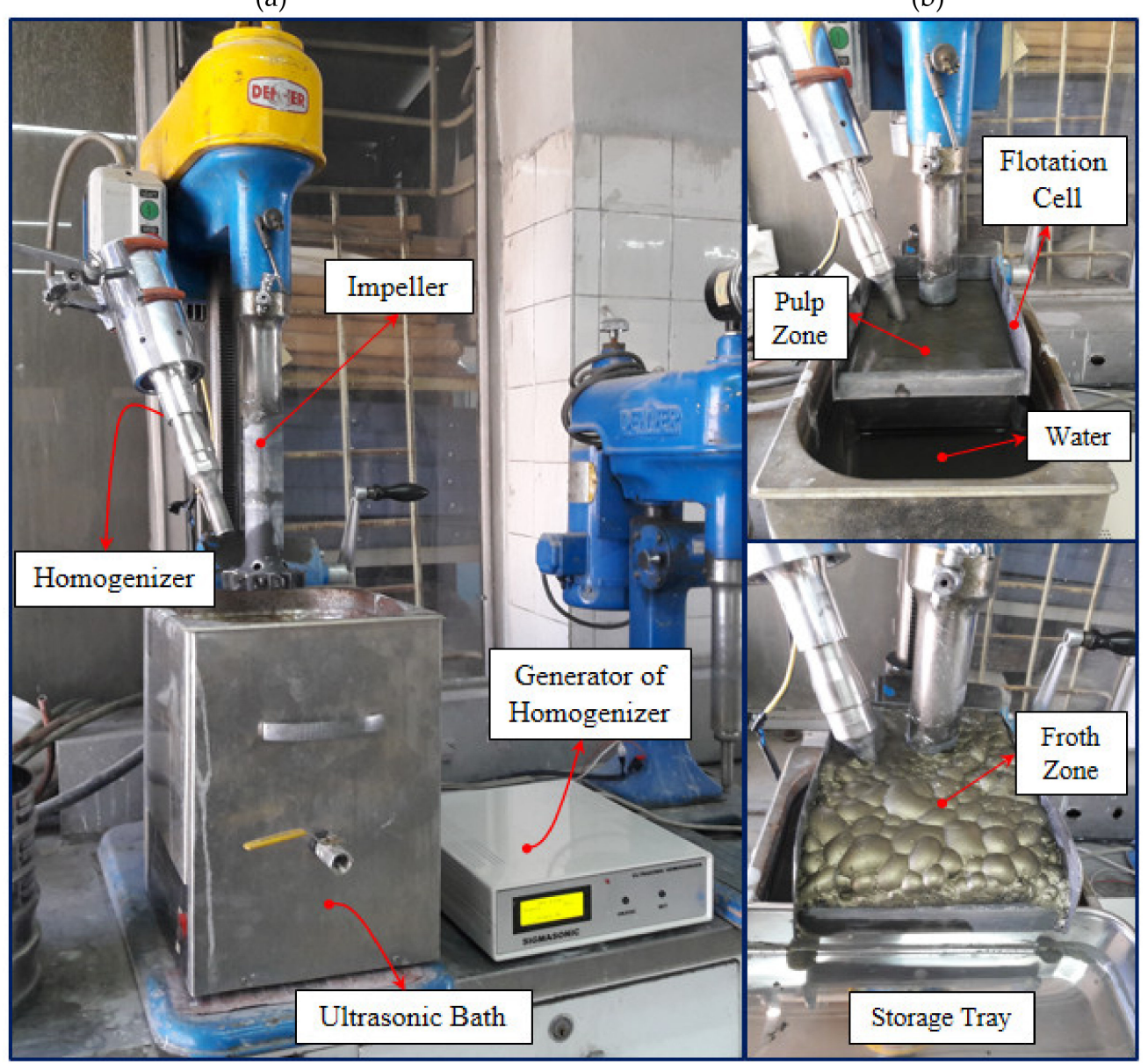

(c)

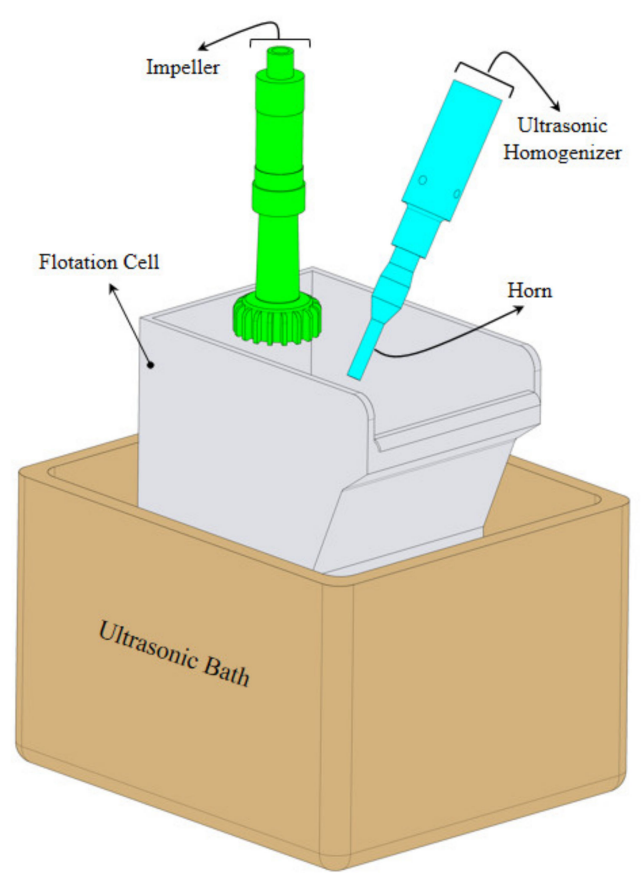

(b) 


\section{Results and Discussions}

\subsection{Effect of the Homogenizer}

The homogenizer was operated at two power levels, namely low $(0.4 \mathrm{~kW})$ and high $(0.8 \mathrm{~kW})$, in order to explore its role in the floatability of materials. Their separation selectivities were compared with the corresponding values of conventional flotation operated in the absence of the ultrasonicator. Figure 3 displays the selectivity indices obtained for chalcopyrite and pyrite in the rougher stage with and without applying the homogenizer. As seen, the selectivity index of chalcopyrite without using sonication and in the presence of the homogenizer operated at $0.8 \mathrm{~kW}$ and $0.4 \mathrm{~kW}$ is $9.3,9.6$, and 9.6, respectively. The respective values for pyrite are 1.2, 1.0, and 1.2. Since particle retention time in this zone is low [66], the ultrasound treatment is more effective on the froth structure and its mobility together with the bubble coalescence than cleaning particle surfaces and increasing the mineral's contact angle. During the flotation experiments, we observed that the small bubbles carrying particles in the froth zone coalesced by acoustic waves and created bigger bubbles, which are deleterious in froth flotation processes, as was shown previously by Hassanzadeh et al. [67,68]. Large bubbles have low stability and high rising velocity, which drops the particle recoveries in this zone. This is in line with the observation of Cilek and Ozgen [34], who reported a wider bubble size distribution by using ultrasound in the froth zone.

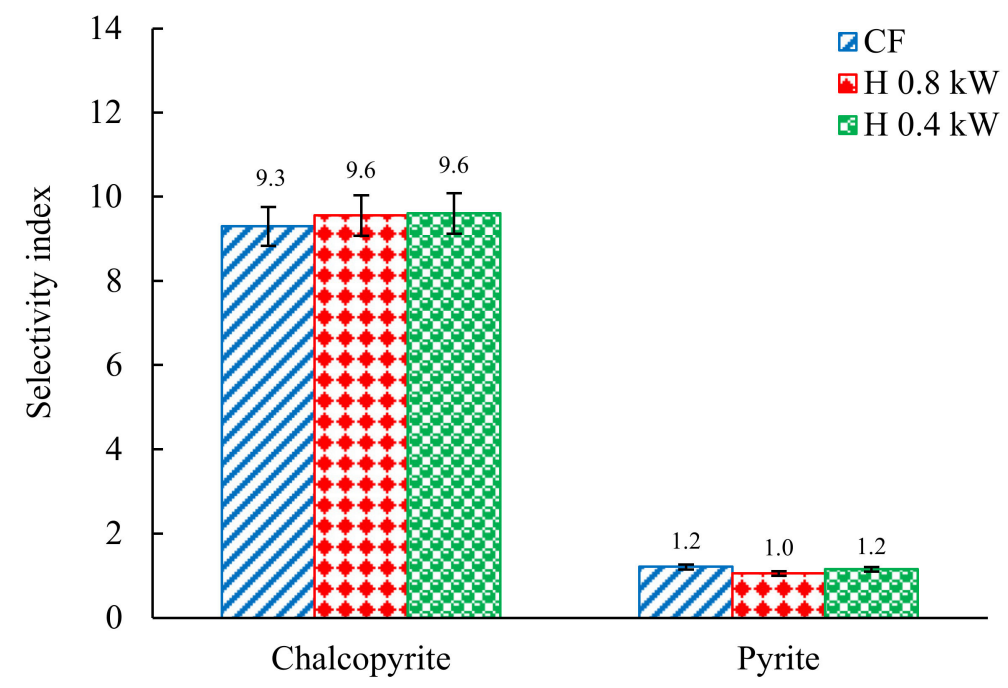

Figure 3. Chalcopyrite and pyrite selectivity indices in the presence and absence of the homogenizer.

Thus, by comparatively analyzing the SI values of the three configurations given in Figure 3, one can conclude that the homogenizer does not significantly affect pyrite and chalcopyrite selectivity indices. In this context, there is little information in the literature, and detailed investigations concerning the role of ultrasonication in frothability, its mobility, and its structure appear to be essential themes for further studies in the future.

In addition to the selectivity indices demonstrated in Figure 3, Table 4 presents the ultimate chalcopyrite and pyrite grades and recoveries. As seen, chalcopyrite grade improves from $21.5 \%$ (conventional flotation) to $25.5 \%$ by being subjected to the homogenizer $(\mathrm{H} 0.8 \mathrm{~kW})$, while its recovery diminishes from $86.4 \%$ to $83.3 \%$. In the case of pyrite under the same conditions, its grade and recovery decrease from $14.8 \%$ and $10.5 \%$ (non-ultrasonic treatment) to $12.6 \%$ and $7.4 \%$, respectively. The results presented by Vargas et al. [69] support our findings. They found that conditioning by means of ultrasonic waves preserved the concentration of copper sulfides, but decreased the recovery of iron sulfides, resulting in the improved selectivity in the flotation, reducing the recovery of pyrite and increasing the grade of concentrate. One reason can be attributed to the entrainment phenomenon, where both gangue minerals (mostly silicates and pyrite) and the mineral of interest (chalcopyrite) are 
trapped within a specific froth structure. The particles selectively attached to the bubbles, together with the particles trapped in this network, vibrate by acoustic waves, which leads to draining both weakly attached chalcopyrite and silicates. The former slightly reduces the recovery of chalcopyrite and the latter increases its grade notably. The presence of silicates/clays and their deleterious effects in the froth zone is a long-standing challenge in flotation processes. It can be categorized into two parts, i.e., (i) the coating of clay minerals on the surface of chalcopyrite and (ii) the formation of network structures in the slurry, which leads to either high pulp viscosity or increased gangue entrainment [70]. This is discussed in detail in Section 3.4. Thus, using homogenizer in the froth zone dominantly affects the grade of chalcopyrite, although it deleteriously impacts on its recovery.

Table 4. Grades and recoveries of chalcopyrite and pyrite obtained in the presence and absence of the homogenizer operated at $0.4 \mathrm{~kW}$ and $0.8 \mathrm{~kW}$.

\begin{tabular}{ccccccc}
\hline Configuration & \multicolumn{2}{c}{ CF } & \multicolumn{2}{c}{ H 0.8 kW } & \multicolumn{2}{c}{ H 0.4 kW } \\
\hline Response & Grade (\%) & Recovery (\%) & Grade (\%) & Recovery (\%) & Grade (\%) & Recovery (\%) \\
\hline Chalcopyrite & 21.5 & 86.4 & 25.5 & 83.3 & 25.7 & 84.0 \\
Pyrite & 14.8 & 10.5 & 12.6 & 7.4 & 14.7 & 8.9 \\
\hline
\end{tabular}

By comparing the application of the homogenizer at two power levels, it can be seen that by decreasing the homogenizer's power, the grade and recovery of chalcopyrite changes from $25.5 \%$ to $25.7 \%$ and $12.6 \%$ to $14.7 \%$, respectively. Additionally, the grade and recovery of pyrite vary from $12.6 \%$ to $14.7 \%$ and $7.4 \%$ to $8.9 \%$, respectively. By taking ultimate grades and recoveries of both chalcopyrite and pyrite into consideration (Table 4), together with the selectivity indices (Figure 3) obtained for all three patterns, we observed that using the homogenizer at $0.4 \mathrm{~kW}$ induces a relative increase of $19.5 \%$ in the recovery of chalcopyrite compared to the conventional flotation. It also desirably reduces pyrite grade and recovery by about $0.6 \%$ and $3.2 \%$, respectively. Therefore, one can conclude that despite the fact that homogenizer does not have a selective separation role and relatively decreases the recovery of chalcopyrite by about $3.0 \%$, it can increase the grade of chalcopyrite and appropriately affect pyrite.

\subsection{Effect of the Ultrasonic Bath}

Figure 4 displays Gaudin's selectivity index for conventional and ultrasonic-assisted rougher flotation of the copper ore. According to the results, by exposing the sample to the ultrasonic bath, the selectivity of chalcopyrite reasonably increases from 9.3 to 10.8 (relatively $16.1 \%$ ), while the respective amount of pyrite slightly reduces from 1.2 to 1.1. The positive improvement is because of the fact that the mechanical vibrations increase the dynamic contact surface of the solid-gas interface, as reported for galena and oxidized pyrite samples, respectively, by Gungoren et al. [47] and Cao et al. [27]. The chalcopyrite's contact angles were obtained as $53.5 \pm 2.3^{\circ}$ and $60.1 \pm 1.5^{\circ}$ in the absence and presence of the ultrasonic bath, respectively, operated for $8 \mathrm{~min}$. The contact angle measurements show that the hydrophobicity of chalcopyrite is promoted by treatment in the ultrasonic bath. The reason for the increasing contact angle has remained unclear in the literature, but it is mainly referred to by the formation of surface submicron (nano)-sized bubbles, which create a bridge between the collector and the mineral surface [71,72]. This phenomenon is the so-called bridging effect or secondary-collector role of the nanobubbles, which induces an increase in the particle-bubble attachment efficiency. These bubbles can be generated by applying ultrasonication due to the hydrodynamic cavitation and hold an extensive lifetime on the solid surface [73]. More detailed information can be found elsewhere [74]. 


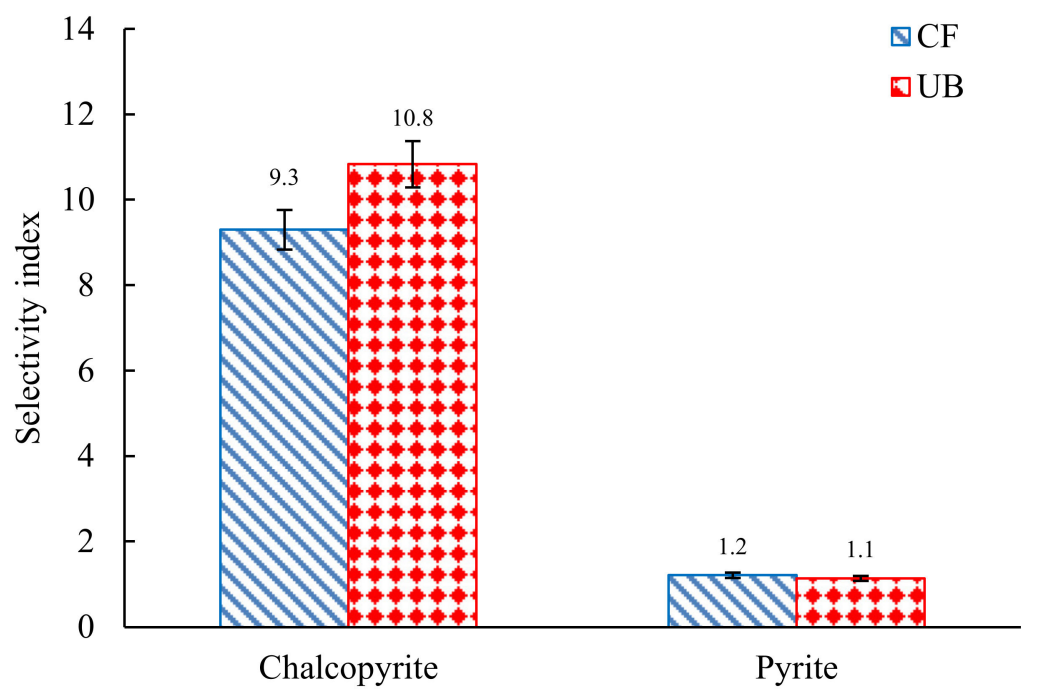

Figure 4. Selectivity indices of chalcopyrite and pyrite with and without the ultrasonic bath.

Another principle reason for the improving chalcopyrite selectivity index is related to the cleaning effect of particle surfaces by ultrasound, which in turn increases the collector absorption by exposing the clean surface of the particle in contact with the surfactant. It forms high-energy centers on the particle surfaces and improves the absorption rate of the reagent molecules. It also makes intense microscale hot spots in solid composites, leading to the hydrophobization of chalcopyrite particles during ultrasonic irradiation [75]. In this context, Kang and Li [76] reported that ultrasonic conditioning not only improved the hydrophobicity of graphite but also eliminated both silicates and other metallic impurities from the surface of graphite. With regard to the favorable adsorption of collectors, Celik [46] demonstrated that the ultrasonic treatment under appropriate conditions could achieve at least a $50 \%$ reduction in collector consumption in the galena/xanthate system. Several researchers $[22,33,35,77]$ documented an improvement of $1-5 \%$ in the copper recovery of various ore samples due to the removal of impurities from the chalcopyrite surface by subjecting it to an ultrasonic treatment process. Therefore, influential factors providing an increase in recoverability of chalcopyrite are as follows: (i) cleaning the slime-coated surface of chalcopyrite, (ii) creating surface micro- and/or nanobubbles, and (iii) improving the collector adsorption rate on chalcopyrite and its relation with increasing temperature. In contrast to the two former cases ( $\mathrm{i}$ and ii), the role of temperature with respect to ultrasonic-assisted flotation in collector adsorption mechanisms and mineral floatability behavior has been rarely explored in the literature.

In contrast to chalcopyrite, the surface of pyrite can be easily oxidized in pulp due to the formation of hydrogen peroxide $\left(\mathrm{H}_{2} \mathrm{O}_{2}\right)$ as a strong oxidant agent that enhances its wettability. This phenomenon was confirmed by Nooshabadi et al. [78], who found a notable concentration of $\mathrm{H}_{2} \mathrm{O}_{2}$ in the pulp during the wet-grinding and flotation of pyrite. The formation of the oxidized surface layer and its elimination have remained an ongoing argument in the literature. Different interpretations can be found in the works of Ozun et al. [45], Cao et al. [27], and Taheri and Lotfalian [79]. For instance, Taheri and Lotfalian [79] studied the ultrasonic pretreatment on an artificial mixture of chalcopyrite and pyrite. They found that the effective separation of chalcopyrite from pyrite was attributed to the desorption of metal hydroxide precipitates, as hydrophilic species, from the surface of the chalcopyrite by ultrasonic treatment. This result can be supported by the conclusion presented by Kang et al. [26], who showed a negative effect on the floatability of pyrite during desulfurization in coal flotation with ultrasonication generated by a UGD model multi-function ultrasonic transmitter $(20 \mathrm{kHz}$ and $0.2 \mathrm{~kW})$.

Table 5 presents the ultimate grades and recoveries acquired in the presence and absence of the ultrasonic bath in the flotation experiments. As shown, ultrasonication slightly drops the recovery of chalcopyrite from $86.4 \%$ to $84.8 \%$ but significantly increases its grade from $21.5 \%$ to $28.9 \%$. In the case of pyrite, the ultrasonic bath changes its grade and recovery by approximately $1.4 \%$ and $27.7 \%$, 
respectively, compared to the conventional flotation process. These differentiations provide an acceptable level of selectivity (i.e., increasing from 9.3 to 10.8) in separating chalcopyrite from pyrite. It is expected that the ultrasonic treatment leads to an increase in the recovery of chalcopyrite, while the experimental results show a slight decrease in its recovery. It seems that as a result of the use of ultrasonic waves, the intensity of mechanical vibration introduced into the bubbles exceeds the level of mechanical strength of a number of bubbles and therefore led to the destruction of these large and unstable bubbles. In this way, the density of the bubbles in the froth phase reduces. The effect of reducing the number of bubbles in the froth phase is greater than the effect of increasing the consistency of chalcopyrite particles in the bubbles on the flotation process. This led to a slight decrease in the recovery of chalcopyrite in the ultrasonic flotation process.

Table 5. Final grades and recoveries of chalcopyrite and pyrite obtained in non-treated and ultrasonic-treated flotation experiments.

\begin{tabular}{ccccc}
\hline Configuration & \multicolumn{2}{c}{ CF } & \multicolumn{2}{c}{ UB } \\
\hline Response & Grade (\%) & Recovery (\%) & Grade (\%) & Recovery (\%) \\
\hline Chalcopyrite & 21.5 & 86.4 & 28.9 & 84.8 \\
Pyrite & 14.8 & 10.5 & 14.6 & 7.6 \\
\hline
\end{tabular}

\subsection{Effect of the Combination of the Ultrasonic Bath with the Homogenizer}

Figure 5 comparatively displays the SI values obtained from the combined effect of the ultrasonic bath with the homogenizer (at $0.4 \mathrm{~kW}$ and $0.8 \mathrm{~kW}$ power levels) and conventional rougher flotation experiments. As seen, the combination of homogenizer and ultrasonic bath at $0.4 \mathrm{~kW}$ and $0.8 \mathrm{~kW}$ provides selectivity indices of 11.8 and 10.3 for chalcopyrite, while the corresponding amount is equal to 9.30 in the traditional flotation system. In other words, the combined ultrasonic bath and homogenizer operated at $0.4 \mathrm{~kW}$ and $0.8 \mathrm{~kW}$ provides $26.9 \%$ and $10.8 \%$ higher chalcopyrite selectivities compared to the non-treated ones. Interestingly, the SI values obtained for pyrite were 1.2 for all the three patterns. The synergetic impact of several effective factors discussed earlier, such as the creation of micro- and/or nanobubbles on mineral surfaces, the surface cleaning by ultrasound, the formation of $\mathrm{H}^{+}$and $\mathrm{OH}^{-}$radicals, changes in the liquid temperature, and dissolved oxygen, leads to such a consequence. Thus, the results indicate that the simultaneous effect of the homogenizer and the ultrasonic treatment during the rougher flotation selectively separates chalcopyrite but does not affect the pyrite. Furthermore, by lowering the power of the homogenizer from $0.8 \mathrm{~kW}$ to $0.4 \mathrm{~kW}$, the chalcopyrite SI value promotes $14.6 \%$, which is in line with the presented results in Table 4 and Figure 3. In this regard, Cao et al. [27] found that the intensity of sonication time was a more determinant parameter than its power for oxidized pyrite. Aldrich and Feng [22] reported that, although the ultrasonic preconditioning improved copper recovery and depressed quartz, prolonged sonication adversely affected chalcopyrite floatability. Although the time and power of ultrasonicators have been studied in the literature, little information has been presented regarding the homogenizer. Therefore, detailed investigations are required in this sense in future works.

By taking selective separation amounts obtained from all configurations into account (Figures 3-5), one can conclude that despite the fact that the homogenizer does not have a significant influence on chalcopyrite's SI, the ultrasonic bath alone and, particularly, its combination with the homogenizer operated at $0.4 \mathrm{~kW}$ provide the highest selectivity index of chalcopyrite (11.8). 


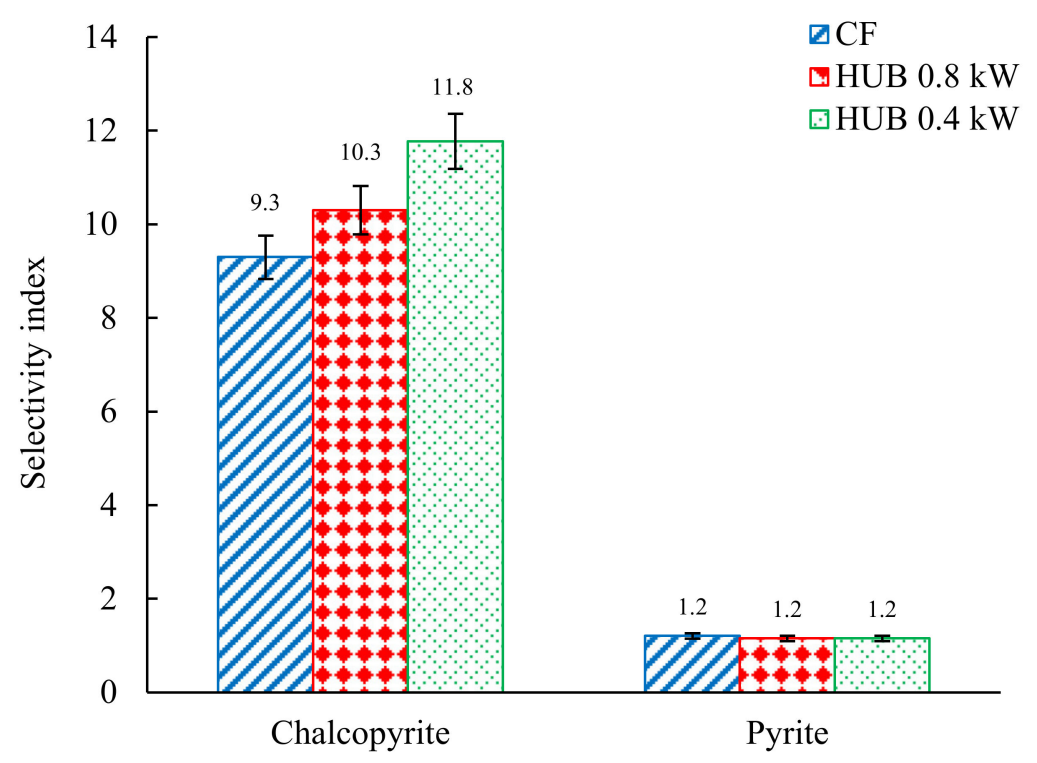

Figure 5. The SI values obtained for chalcopyrite and pyrite at three different configurations in the rougher flotation stage.

Table 6 shows the final grades and recoveries related to the combination of the ultrasonic bath with the homogenizer. As seen, in the absence of acoustic waves, the ultimate grade and recovery of chalcopyrite and pyrite are $21.5 \%$ and $86.4 \%$, and $14.8 \%$ and $10.5 \%$, respectively. If the ultrasonic bath and homogenizer (at $0.4 \mathrm{~kW}$ power) operate simultaneously, both grade and recovery of chalcopyrite relatively improve by about $18.1 \%$ and $2.8 \%$. Meanwhile, the respective values for pyrite reach $15.4 \%$ and $9.1 \%$, respectively. By considering Tables $4-6$, using either the homogenizer or the ultrasonic bath reduces the recovery of chalcopyrite to some extent compared to the results of conventional flotation; however, the combination of the homogenizer $(0.4 \mathrm{~kW})$ and the ultrasonic bath increases its recovery from $86.4 \%$ to $88.8 \%$. This configuration reduces the intensity of mechanical vibrations entering the bubbles due to the phenomenon of wave interference. Therefore, fewer bubbles collapse and fail, especially in the froth zone. This reduces the destructive effect of using ultrasonic waves on the recovery of chalcopyrite. For this reason, using an ultrasonic bath and a homogenizer with the power of $0.4 \mathrm{~kW}$ increases the recovery of chalcopyrite.

Table 6. Final grades and recoveries of chalcopyrite and pyrite obtained without the acoustic waves and with a combination of homogenizer and ultrasonic bath.

\begin{tabular}{ccccccc}
\hline Configuration & \multicolumn{2}{c}{ CF } & \multicolumn{2}{c}{ HUB 0.8 kW } & \multicolumn{2}{c}{ HUB 0.4 kW } \\
\hline Response & Grade (\%) & Recovery (\%) & Grade (\%) & Recovery (\%) & Grade (\%) & Recovery (\%) \\
\hline Chalcopyrite & 21.5 & 86.4 & 26.9 & 84.6 & 25.4 & 88.8 \\
Pyrite & 14.8 & 10.5 & 14.9 & 8.3 & 15.4 & 9.1 \\
\hline
\end{tabular}

In order to investigate the effect of input parameters (including vibration power and type of applied vibration) on the grade and recovery of chalcopyrite, an analysis of variance of experimental results was performed using Minitab ${ }^{\circledR}$ software V. 16.2.4 (Minitab Inc., State College, Pennsylvania, U.S.A.) with $95 \%$ confidence level. The distribution percentages in Table 7 show the degree to which the input parameters affect the output results of the rougher flotation process in the 8th minute. As shown, the vibrational process type with $82.1 \%$ and $88.8 \%$ affecting percentages is still the most important factor influencing the recovery and grade of chalcopyrite. 
Table 7. Results of the analysis of variance for chalcopyrite grade and recovery in the rougher stage.

\begin{tabular}{|c|c|c|c|c|c|c|}
\hline \multirow{2}{*}{ Source } & \multirow{2}{*}{$\mathrm{DF}^{*}$} & \multirow{2}{*}{ Reduced DF } & \multicolumn{2}{|r|}{ Grade } & \multicolumn{2}{|c|}{ Recovery } \\
\hline & & & Seq SS * & Contribution (\%) & Seq SS * & Contribution (\%) \\
\hline Types of process & 3 & 3 & 3.2 & 88.8 & 1.6 & 82.1 \\
\hline $\begin{array}{c}\text { Power of } \\
\text { homogenizer }\end{array}$ & 2 & 1 & 0.4 & 11.1 & 0.4 & 17.7 \\
\hline Error & 0 & 1 & 0.0 & 0.1 & 0.0 & 0.2 \\
\hline Total & 5 & 5 & 3.6 & 100.0 & 2.0 & 100.0 \\
\hline
\end{tabular}

${ }^{*} \mathrm{DF}$ is degree of freedom and SS denotes sum of squares.

\subsection{Entrainment and Water Recovery in the Re-Cleaner Stage}

The rougher stage mainly aims at increasing recovery, while the re-cleaner one improves the quality of the product (grade). In this perspective, ultrasonic-assisted re-cleaner flotation tests were conducted in addition to the rougher flotation experiments as presented in previous sections. To ease the interpretation of the results, the combination of the homogenizer (at $0.8 \mathrm{~kW}$ ) with the ultrasonic bath was disregarded in this stage.

Figure 6 exhibits the practical cumulative grade-recovery curves of two very dominant metalloid gangue components (i.e., $\mathrm{SiO}_{2}$ and $\mathrm{Al}_{2} \mathrm{O}_{3}$ ) in the re-cleaner stage. A shift upward and to the right (for the target mineral) as well as to the left and downward (for the gangue minerals) indicates an improvement in separation performance [80]. As seen in Figure 6a,b, using the homogenizer (at $0.8 \mathrm{~kW})$ followed by $\mathrm{H} 0.4 \mathrm{~kW}$ situates in the left corner side of the graph showing the least number of grades and recoveries. However, the grade-recovery curve in the conventional treatment process locates to the very right side containing the highest content of $\mathrm{SiO}_{2}$ and $\mathrm{Al}_{2} \mathrm{O}_{3}$ in comparison to the rest of the configurations. Therefore, applying the homogenizer without adding the ultrasonic bath is a favorable treatment for obtaining higher grades in the cleaning stage.

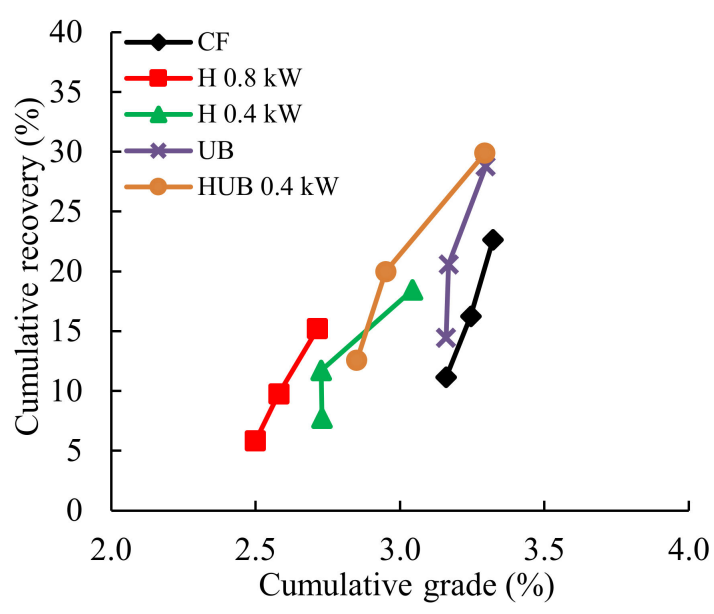

(a)

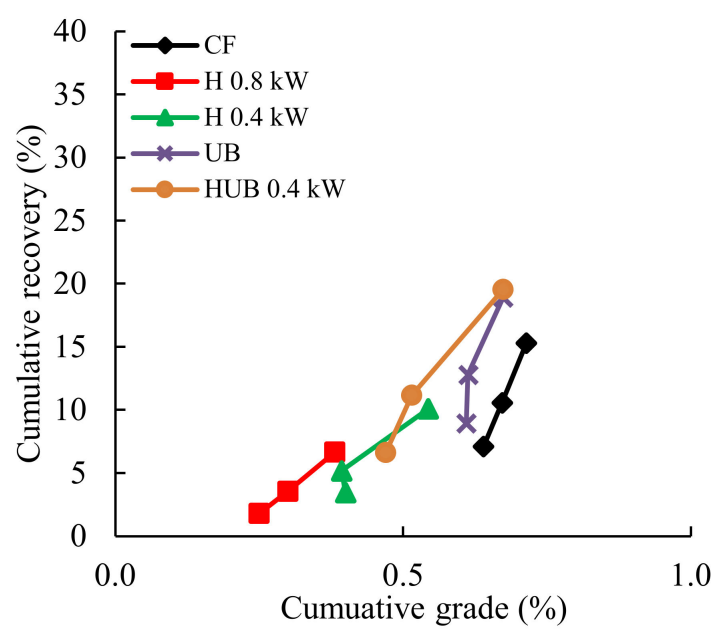

(b)

Figure 6. Grade and recovery curves for $(\mathbf{a}) \mathrm{SiO}_{2}$ and (b) $\mathrm{Al}_{2} \mathrm{O}_{3}$ at the re-cleaner stage.

As shown in Table 2, muscovite and illite comprise $25.50 \mathrm{wt} \%$ and $27.80 \mathrm{wt} \%$ of the ore, respectively, as the main clay minerals. The presence of muscovite and illite along with quartz, calcite, albite, and clinochlore adversely affects the rheology of the slurry, froth structure, and its stability. The hydrophilic layer created by these minerals can be physically removed by acoustic waves; nevertheless, further mineralogical data containing mineral associations are required to support such a statement in this work. In this regard, Uribe et al. [81] documented that the recovery of slime-coated chalcopyrite was reduced compared to the pure chalcopyrite sample, which was related to the existence of hydrophilic particles such as clay minerals on the surface of the chalcopyrite. Studies performed 
by Özkan and Kuyumcu [29], Özkan [38], Farmer et al. [24], and Peng et al. [6] proved that the improvement in these values was due to the effective cleaning of the particle surfaces and consequently decreased their entrainment rates. Mechanical vibration caused by the ultrasonic waves drops the particles from the surface of the bubbles, leading them to sink into the pulp. Moreover, acoustic waves reduce the trapping of these particles between the bubbles and their entrainment, leading them to concentrate in the froth phase. Lowering silicate-based components in the froth zone induces a non-rigid froth structure, which is a crucial factor in achieving a favorable grade. Thus, the reduction in these reagent-consuming components favors particle-bubble attachment and leaves sufficient dosage of the collector to chalcopyrite particles to be covered and float to the froth zone [82].

The fraction of total water in the flotation cell recovered to the concentrate is defined as water recovery. It is also used as an indicator for the entrainment degree and froth properties [83]. Figure 7 comparatively displays the water recovery in both the rougher and re-cleaner stages in the presence of all different operating configurations. As seen, water recoveries in the rougher stage are always higher than in the re-cleaner one because of greater mass pool rates in the rougher stage. Furthermore, applying sonication reduces water recovery to the concentrate in comparison to the conventional flotation. This is related to the ultrasonic effect on reducing the entrainment of particles on the concentrate. The mechanical vibration of the bubbles because of ultrasonic waves reduces the transfer of water droplets from the pulp phase to the bubbles (during the froth production stage) and also diminishes the trapping of these droplets between the bubbles and thus increases their return to the pulp phase. Therefore, the use of ultrasonic waves reduces water recovery in the flotation process (Figure 7).

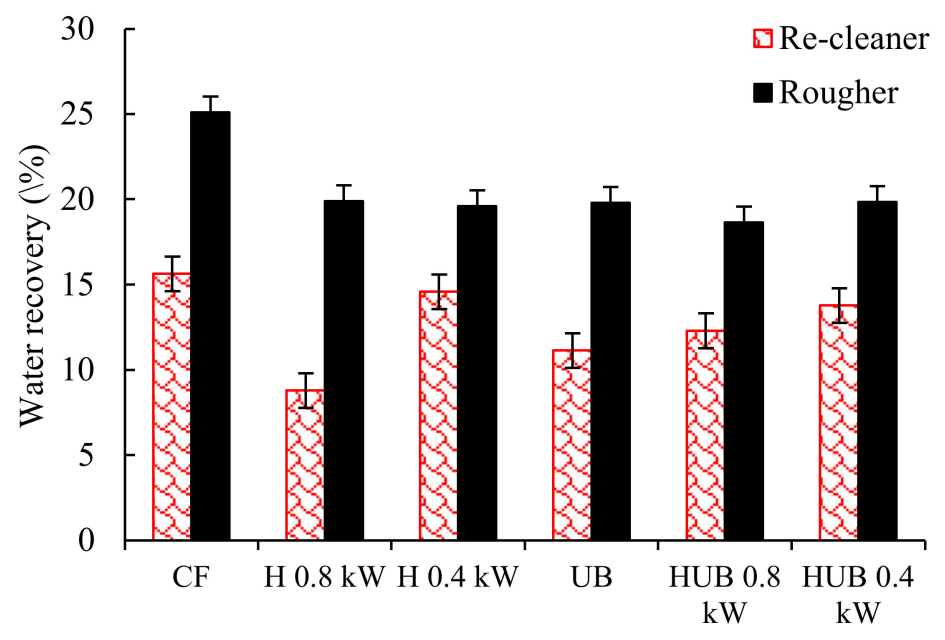

Figure 7. Water recovery to concentrate for both the rougher and re-cleaner stages.

\section{Conclusions and Recommendations}

The present study focused on determining the impact of four variant operating configurations with respect to simultaneous ultrasonication and batch flotation in a copper complex ore. These different operations used conventional flotation, homogenizer, ultrasonic bath, and a combination of homogenizer and ultrasonic bath, which were examined in both rougher and re-cleaner flotation stages. The ultrasonic vibration was generated during the flotation using a homogenizer and an ultrasonic bath at the froth and bulk zones, respectively. The rougher and re-cleaner flotation experiments were conducted in $4.2 \mathrm{~L}$ and $1 \mathrm{~L}$ Denver-type mechanically agitated cells.

The comparative analysis between the chalcopyrite and pyrite SI values obtained from the traditional flotation process and using a homogenizer as the ultrasonic source at two power levels disclosed that the homogenizer did not have a significant impact on the selective separation of pyrite and chalcopyrite. Nevertheless, applying the homogenizer at $0.4 \mathrm{~kW}$ induced a relative improvement of $19.5 \%$ in the recovery of chalcopyrite compared to the conventional flotation. It also lowered pyrite grade and recovery by about $0.6 \%$ and $3.2 \%$, respectively. Exposing the sample to the ultrasonic 
bath upgraded the selectivity of chalcopyrite from 9.3 to 10.8, although the corresponding amount of pyrite dropped slightly from 1.2 to 1.1. Furthermore, the recovery of chalcopyrite was reduced from $86.4 \%$ to $84.8 \%$, but its grade was considerably increased from $21.5 \%$ to $28.9 \%$. In the case of pyrite, the ultrasonic bath changed its grade and recovery by approximately $1.4 \%$ and $27.7 \%$, respectively. Mechanical vibration increased the chalcopyrite's contact angle from $53.5 \pm 2.3^{\circ}$ to $60.1 \pm 1.5^{\circ}$ due to the synergetic effect of the increasing temperature, the formation of submicron (nano)-sized bubbles on mineral surfaces, and most importantly the cleaning of particle surfaces in the bulk solution. Additionally, the results showed that if the ultrasonic bath and the homogenizer (at $0.4 \mathrm{~kW}$ power) operated simultaneously during the rougher flotation, chalcopyrite could be selectively separated by upgrading its grade and recovery by about $18.1 \%$ and $2.8 \%$. Finally, it was concluded that in addition to the power and time of ultrasonication, its configuration is another critical factor in ultrasonic-assisted flotation processes. Operating a combination of the ultrasonic bath with the homogenizer (at $0.4 \mathrm{~kW}$ power) in the rougher stage was selected as the most favorable configuration in this study with respect to the given amounts of selectivity, grade, and recovery. In the cleaning stage, however, the results showed that applying the homogenizer without adding the ultrasonic bath was a favorable treatment to gain higher grades.

According to the results obtained in this work, arguments, and the information given in the literature, many unknown phenomena occur in the application of ultrasonic-assisted flotation processes. These knowledge gaps require further study in future works. We have listed the major points as follows:

1. The impact of acoustic waves on the particle surface, especially its surface roughness charges and zeta potential charge, is unclear. Further investigations are highly recommended in this regard.

2. Little attention has been drawn to the role of acoustic waves in microscopic subprocesses of particle-bubble interactions, particularly attachment and detachment efficiencies. Future studies are required to explore these processes.

3. Although improvement in recoverability of valuable minerals on the laboratory scale is extensively documented, there is a considerable lack of industrial surveys concerning the application of ultrasonication to froth flotation. Further studies are recommended in this sense.

4. Interestingly, the role of effective parameters including liquid temperature, conductivity, dissolved oxygen level, $\mathrm{pH}$, and, most importantly, solution chemistry together with their interconnection effects have rarely been reported in the literature. Therefore, studies are suggested in this regard.

5. Although ultrasonic-assisted flotation in the bulk zone of a mechanical flotation cell has been adequately investigated, the froth zone and its characteristics (e.g., froth structure, frothability, and its mobility) need further detailed studies.

Author Contributions: Conceptualization, H.G.; S.A.S., A.H. and S.A.; Methodology, H.G.; S.A.S. and A.H.; Original draft preparation: A.H.; Writing, reviewing and editing, A.H.; H.G. and S.G.Ö.; Investigation, A.H.; S.A.S. and H.G.; Visualization and supervision, A.H. and S.A. We authors have read and agreed to the published version of the manuscript. All authors have read and agreed to the published version of the manuscript.

Funding: This research received no external funding.

Acknowledgments: The authors are indebted to National Iranian Copper Industries Company (NICICO) for generously supporting this research. Additionally, special thanks are given to the staff of the Sarcheshmeh copper complex at the pilot plant and the Research and Development Division for their consistent assistance. The first author is grateful to the journal Minerals and the Committee of the 2020 Minerals Travel Awards as well as the Helmholtz Institute Freiberg for Resource Technology (Germany) for their supports. Additionally, we would like to thank the anonymous reviewers for their insightful remarks, constructive comments, and fruitful criticisms.

Conflicts of Interest: The authors declare no conflict of interest. 


\section{References}

1. Mason, T.J.; Lorimer, J.P. Applied Sonochemistry: Uses of Power Ultrasound in Chemistry and Processing, 1st ed.; Wiley-VCH: Hoboken, NJ, USA, 2002.

2. Suslick, K.S. Sonochemistry. Science 1990, 247, 1439-1445. [CrossRef] [PubMed]

3. Doktycz, S.J.; Suslick, K.S. Interparticle collisions driven by ultrasound. Science 1990, 247, 1067-1069. [CrossRef] [PubMed]

4. Li, B.; Liu, S.; Guo, J.; Zhang, L.; Sun, X. Increase in wettability difference between organic and mineral matter to promote low-rank coal flotation by using ultrasonic treatment. Appl. Surface Sci. 2019, 481, 454-459. [CrossRef]

5. Vyas, S.; Ting, Y. A review of the application of ultrasound in bioleaching and insights from sonication in (bio)chemical processes. Resources 2018, 7,3. [CrossRef]

6. Peng, Y.; Mao, Y.; Xia, W.; Li, Y. Ultrasonic flotation cleaning of high-ash lignite and its mechanism. Fuel 2018, 220, 558-566. [CrossRef]

7. Zheng, C.; Ru, Y.; Xu, M.; Zhen, K.; Zhang, H. Effects of ultrasonic pretreatment on the flotation performance and surface properties of coking middlings. Energy Sources Part A Recovery Util Environ. Eff. 2018, 40, 734-741. [CrossRef]

8. Mao, Y.; Xia, W.; Peng, Y.; Xie, G. Ultrasonic-assisted flotation of fine coal: A review. Fuel Process. Technol. 2019, 195. [CrossRef]

9. Chen, Y.; Truong, V.N.T.; Bu, X.; Xie, G. A review of effects and applications of ultrasound in mineral flotation. Ultrason. Sonochem. 2020, 60. [CrossRef]

10. Swamy, K.M.; Rao, K.S.; Narayana, K.L.; Murty, J.S.; Ray, H.S. Application of ultrasound in leaching. Miner. Process. Extr. Metall. Rev. 1995, 14, 179-192. [CrossRef]

11. Luque-Garcia, J.L.; Luque de Castro, M.D. Ultrasound: A powerful tool for leaching. TrAC Trends Anal. Chem. 2003, 22, 41-47. [CrossRef]

12. Azizi, A.; Hassanzadeh, A.; Fadaei, B. Investigating the first-order flotation kinetics models for Sarcheshmeh copper sulfide ore. Int. J. Min. Sci. Technol. 2015, 25, 849-854. [CrossRef]

13. Hassanzadeh, A.; Firouzi, M.; Albijanic, B.; Celik, M.S. A review on determination of particle-bubble encounter using analytical, experimental and numerical methods. Miner. Eng. 2018, 122, 296-311. [CrossRef]

14. Hassanzadeh, A.; Azizi, A.; Kouachi, S.; Karimi, M.; Celik, M.S. Estimation of flotation rate constant and particle-bubble interactions considering key hydrodynamic parameters and their interrelations. Miner. Eng. 2019, 141, 1-18. [CrossRef]

15. Galvin, K.P.; Harvey, N.G.; Dickinson, J.E. Fluidized bed desliming in fine particle flotation-Part III flotation of difficult to clean coal. Miner. Eng. 2014, 66, 94-101. [CrossRef]

16. Rabatho, J.P.; Tongamp, W.; Shibayama, A.; Takasaki, Y.; Nitta, S.; Imai, T. Investigation of a flotation process with de-sliming and attrition to upgrade and recover $\mathrm{Cu}$ and $\mathrm{Mo}$ from a $\mathrm{Cu}-\mathrm{Mo}$ flotation tailing. Mater. Trans. 2011, 52, 746-752. [CrossRef]

17. Liu, C.; Song, S.; Li, H.; Ai, G. Sulfidization flotation performance of malachite in the presence of calcite. Miner. Eng. 2019, 132, 293-296. [CrossRef]

18. Shu, K.; Xu, L.; Wu, H.; Fang, S.; Wang, Z.; Xu, Y.; Zhang, Z. Effects of ultrasonic pre-treatment on the flotation of ilmenite and collector adsorption. Miner. Eng. 2019, 137, 124-132. [CrossRef]

19. Kingman, S.W. Recent developments in microwave processing of minerals. Int. Mater. Rev. 2006, 51, 1-12. [CrossRef]

20. Gholami, H.; Rezai, B.; Mehdilo, A.; Hassanzadeh, A.; Yarahmadi, M.R. Effect of microwave system location on floatability of chalcopyrite and pyrite in a copper ore processing circuit. Physicochem. Probl. Miner. Process. 2020, 56, 432-448. [CrossRef]

21. Gholami, H.; Rezai, B.; Hassanzadeh, A.; Mehdilo, A.; Behjat Jabbari, M. The effect of microwave's location in a comminution circuit on improving grindability of a porphyry copper deposit. Energy Sources Part A Recovery Util. Environ. Eff. 2020, 1-20. [CrossRef]

22. Aldrich, C.; Feng, D. Effect of ultrasonic preconditioning of pulp on the flotation of sulphide ores. Miner. Eng. 1999, 12, 701-707. [CrossRef]

23. Kowalski, W.; Kowalska, E. The ultrasonic activation of non-polar collectors in the flotation of hydrophobic minerals. Ultrasonics 1978, 16, 84-86. [CrossRef] 
24. Farmer, A.D.; Collings, A.F.; Jameson, G.J. Effect of ultrasound on surface cleaning of silica particles. Int. J. Miner. Process. 2000, 60, 101-113. [CrossRef]

25. Astashev, V.K.; Babitsky, V.I. Ultrasonic processes and machines: Dynamics, control and applications. In Ultrasonic Processes and Machines, Foundations of Engineering Mechanics; Springer: Berlin/Heidelberg, Germany, 2007; pp. 332-333. [CrossRef]

26. Kang, W.; Xun, H.X.; Kong, X.H.; Li, M.M. Effects from changes in pulp nature after ultrasonic conditioning on high-sulfur coal flotation. Min. Sci. Technol. 2009, 19, 498-507. [CrossRef]

27. Cao, Q.; Cheng, J.; Feng, Q.; Wen, S.; Luo, B. Surface cleaning and oxidative effects of ultrasonication on the flotation of oxidized pyrite. Powder Technol. 2017, 311, 390-397. [CrossRef]

28. Özkan, S..G.; Kuyumcu, H.Z. Investigation of mechanism of ultrasound on coal flotation. Int. J. Miner. Process. 2006, 81, 201-203. [CrossRef]

29. Özkan, S..G.; Kuyumcu, H.Z. Design of a flotation cell equipped with ultrasound transducers to enhance coal flotation. Ultrason. Sonochem. 2007, 14, 639-645. [CrossRef]

30. Özkan, Ş.G. Effects of simultaneous ultrasonic treatment on flotation of hard coal slimes. Fuel 2012, 93, 576-580. [CrossRef]

31. Özkan, Ş.G. Further investigations on simultaneous ultrasonic coal flotation. Minerals 2017, 7, 177. [CrossRef]

32. Özkan, S.G. A review of simultaneous ultrasound-assisted coal flotation. J. Min. Environ. 2018, 9, 679-689. [CrossRef]

33. Videla, A.R.; Morales, R.; Saint-Jean, T.; Gaete, L.; Vargas, Y.; Miller, J.D. Ultrasound treatment on tailings to enhance copper flotation recovery. Miner. Eng. 2016, 99, 89-95. [CrossRef]

34. Cilek, E.C.; Ozgen, S. Effect of ultrasound on separation selectivity and efficiency of flotation. Miner. Eng. 2009, 22, 1209-1217. [CrossRef]

35. Hernández, Y.V.; Garretón, L.G.; Ortega, L.M.; Belmar, R.V. High-power ultrasound as an alternative to high-intensity conditioning in flotation. In Proceedings of the WCU, Paris, France, 7-10 September 2003; pp. 435-438.

36. Özkan, Ş.G.; Veasey, T.J. Effect of simultaneous ultrasonic treatment on colemanite flotation. In Proceedings of the 6th International Mineral Processing Symposium, Kuşadas1, Turkey, 24-26 September 1996; pp. 277-281.

37. Fangs, S.; Xu, L.; Wuh, H.; Xu, Y.; Wang, Z.; Shu, K.; Hu, Y. Influence of surface dissolution on sodium oleate adsorption on ilmenite and its gangue minerals by ultrasonic treatment. Appl. Surface Sci. 2020, 500, 1-12. [CrossRef]

38. Özkan, Ş.G. Beneficiation of magnesite slimes with ultrasonic treatment. Miner. Eng. 2002, 15, 99-101. [CrossRef]

39. Hassani, F.; Noaparast, M.; Shahaei Tonkaboni, S.Z. A study on the effect of ultrasound irradiation as pretreatment method on flotation of sedimentary phosphate rock with carbonate-silicate gangue. Iran. J. Sci. Technol. Trans. A Sci. 2019, 43, 2787-2798. [CrossRef]

40. Gurpinar, G.; Sonmez, E.; Bozkurt, V. Effect of ultrasonic treatment on flotation of calcite, barite and quartz. Miner. Process. Extr. Metall. (Trans. Inst. Min. Metall. Sect. C 2004, 113, 91-95. [CrossRef]

41. Misra, M.; Raichur, A.M.; Lan, A.P. Improved flotation of arsenopyrite by ultrasonic pretreatment. Miner. Metall. Process. 2003, 20, 93-96. [CrossRef]

42. Haghi, H.; Noaparast, M.; Shafaei Tonkaboni, S.Z.; Mirmohammadi, M. A new experimental approach to improve the quality of low grade silica; the combination of indirect ultrasound irradiation with reverse flotation and magnetic separation. Minerals 2016, 6, 121. [CrossRef]

43. Gungoren, C.; Ozdemir, O.; Özkan, S.G. Effects of temperature during ultrasonic conditioning in quartz-amine flotation. Physicochem. Probl. Miner. Process. 2017, 53, 687-698. [CrossRef]

44. Gungoren, C.; Ozdemir, O.; Wang, X.; Özkan, S.G.; Miller, J.D. Effect of ultrasound on bubble-particle interaction in quartz-amine flotation system. Ultrason. Sonochem. 2019, 52, 446-454. [CrossRef]

45. Ozun, S.; Vaziri Hassas, B.; Miller, J.D. Collectorless flotation of oxidized pyrite. Colloids Surf. A Physicochem. Eng. Asp. 2019, 561, 349-356. [CrossRef]

46. Celik, M.S. Effect of ultrasonic treatment on the floatability of coal and galena. Sep. Sci. Technol. 1989, 24, 1159-1166. [CrossRef]

47. Gungoren, U.; Baktarhan, Y.; Demir, I.; Ozkan, S.G. Enhancement of galena-potassium ethyl xanthate flotation systemby low power ultrasound. Trans. Nonferrous Met. Soc. China 2020, 30, 1102-1110. [CrossRef] 
48. Malayoglu, U.; Özkan, S.G. Effects of ultrasound on desliming prior to feldspar flotation. Minerals 2019, 9, 784. [CrossRef]

49. Ghadyani, A.; Noaparast, M.; Shafaei Tonkaboni, S.Z. A study on the effects of ultrasonic irradiation as pretreatment method on high-ash coal flotation and kinetics. Int. J. Coal Prep. Util. 2018, 38, 374-391. [CrossRef]

50. Hassanzadeh, A. Increasing primary grinding circuit efficiency considering grinding capacity enhancement. In Proceedings of the XVI Balkan Mineral Processing Congress, Belgrade, Serbia, 17-19 June 2015; pp. 171-177.

51. Hassanzadeh, A. A survey on troubleshooting of closed-circuit grinding system. Can. Metall. Q. 2018, 57, 328-340. [CrossRef]

52. Poorkani, M.; Banisi, S. Industrial use of nitrogen in flotation of molybdenite at the Sarcheshmeh copper complex. Miner. Eng. 2005, 18, 735-738. [CrossRef]

53. Hassanzadeh, A. Measurement and modeling of residence time distribution of overflow ball mill in continuous closed circuit. Geosyst. Eng. 2017, 20, 251-260. [CrossRef]

54. Hassanzadeh, A.; Karakas, F. Recovery improvement of coarse particles by stage addition of reagents in industrial copper flotation circuit. J. Dispers. Sci. Technol. 2017, 38, 309-316. [CrossRef]

55. Hassanzadeh, A.; Karakas, F. The kinetics modeling of chalcopyrite and pyrite, and the contribution of particle size and sodium metabisulfite to the flotation of copper complex ores. Part. Sci. Technol. 2017, 35, 455-461. [CrossRef]

56. Agheli, S.; Hassanzadeh, A.; Vaziri Hassas, B.; Hasanzadeh, M. Effect of pyrite content of feed and configuration of locked particles on rougher flotation of copper in low and high pyritic ore types. Int. J. Min. Sci. Technol. 2018, 28, 167-176. [CrossRef]

57. Hassanzadeh, A.; Hasanzadeh, M. A study on selective flotation in low and high pyritic copper sulphide ores. Sep. Sci. Technol. 2016, 51, 2214-2224. [CrossRef]

58. Gholami, H.; Rezai, B.; Hassanzadeh, A.; Mehdilo, A.; Yarahmadi, M.R. Effect of microwave pretreatment on grinding and flotation kinetics of copper complex ore. Int. J. Miner. Metall. Mater. 2020. [CrossRef]

59. Hassanzadeh, A.; Hoang, D.H.; Brockmann, M. Assessment of flotation kinetics modeling using information criteria; case studies of elevated-pyritic copper sulfide and high-grade carbonaceous sedimentary apatite ores. J. Dispers. Sci. Technol. 2020, 41, 1083-1094. [CrossRef]

60. Hassanzadeh, A.; Hasanzadeh, M. Chalcopyrite and pyrite floatabilities in the presence of sodium sulfide and sodium metabisulfite in a high pyritic copper complex ore. J. Dispers. Sci. Technol. 2017, 38, 782-788. [CrossRef]

61. Gaudin, A.M. Principles of Mineral Dressing, 1st ed.; McGraw-Hill Inc.: New York, NY, USA, 1939.

62. Irannajad, M.; Salmani Nuri, O.; Allahkarami, E. A new approach in separation process evaluation. Efficiency ratio and upgrading curves. Physicochem. Probl. Miner. Process. 2018, 54, 847-857. [CrossRef]

63. Duong, H.H.; Hassanzadeh, A.; Peuker, U.A.; Rudolph, M. Impact of flotation hydrodynamics on the optimization of fine-grained carbonaceous sedimentary apatite ore beneficiation. Powder Technol. 2019, 345, 223-233. [CrossRef]

64. Salmani Nuri, O.; Allahkarami, E.; Abdollahzadeh, A. Modeling and optimization of SE and SI of copper flotation via hybrid GA-ANN. Trans. Indian Inst. Met. 2017, 70, 2255-2263. [CrossRef]

65. Shi, S.; Liu, Z.-G.; Sun, J.-T.; Zhang, M.; Du, G.-S.; Li, D. Study of errors in ultrasonic heat meter measurements caused by impurities of water based on ultrasonic attenuation. J. Hydrodyn. Ser. B 2015, 27, 141-149. [CrossRef]

66. Hoang, D.H.; Heitkam, S.; Kupka, N.; Hassanzadeh, A.; Peuker, U.A.; Rudolph, M. Froth properties and entrainment in lab-scale flotation: A case of carbonaceous sedimentary phosphate ore. Chem. Eng. Res. Des. 2019, 142, 100-110. [CrossRef]

67. Hassanzadeh, A.; Vaziri Hassas, B.; Kouachi, S.; Brabcova, Z.; Celik, M.S. Effect of bubble size and velocity on collision efficiency in chalcopyrite flotation. Colloids Surf. A Physicochem. Eng. Asp. 2016, 498, 258-267. [CrossRef]

68. Hassanzadeh, A.; Kouachi, S.; Hasanzadeh, M.; Celik, M.S. A new insight to the role of bubble properties on inertial effect in particle-bubble interaction. J. Dispers. Sci. Technol. 2017, 38, 953-960. [CrossRef]

69. Vargas, Y.; Gaete, L.; Gallego, J.; Montoya, F.; Villanueva, A. Acondicionamiento acústico de alta intensidad. Congr. Iberoam. Acústica 2006, 1-9. 
70. Chen, X.; Peng, Y. Managing clay minerals in froth flotation-A critical review. Miner. Process. Extr. Metall. Rev. 2018, 39, 289-307. [CrossRef]

71. Calgaroto, S.; Azevedo, A.; Rubio, J. Flotation of quartz particles assisted by nanobubbles. Int. J. Miner. Process. 2015, 137, 64-70. [CrossRef]

72. Nazari, S.; Shafaei, S.Z.; Shahbazi, B.; Chehreh Chelgani, S. Study relationships between flotation variables and recovery of coarse particles in the absence and presence of nanobubble. Colloids Surf. A Physicochem. Eng. Asp. 2018, 559, 284-289. [CrossRef]

73. Jadhav, A.J.; Barigou, M. Bulk nanobubbles or not nanobubbles: That is the question. Langmuir 2020, 36, 1699-1708. [CrossRef]

74. Rulyov, N.N.; Filippov, L.O.; Kravchenko, O.V. Combined microflotation of glass beads. Colloids Surf. A Physicochem. Eng. Asp. 2020, 598, 124810. [CrossRef]

75. You, S.; Chen, M.-W.; Dlott, D.D.; Suslick, K.S. Ultrasonic hammer produces hot spots in solids. Nat. Commun. 2015, 6, 6581. [CrossRef]

76. Kang, W.; Li, H. Enhancement of flaky graphite cleaning by ultrasonic treatment. R. Soc. Open Sci. 2019, 6, 191160. [CrossRef]

77. Filippov, L.O.; Matinin, A.S.; Samiguin, V.D.; Filippova, I.V. Effect of ultrasound on flotation kinetics in the reactor-separator. J. Phys. Conf. Ser. 2013, 416, 1-6. [CrossRef]

78. Nooshabadi, A.J.; Larsson, A.C.; Kota, H.R. Formation of hydrogen peroxide by pyrite and its influence on flotation. Miner. Eng. 2013, 49, 128-134. [CrossRef]

79. Taheri, B.; Lotfalian, M. Effect of ultrasonic pre-treatment and aeration on flotation separation of chalcopyrite from pyrite. Iran. J. Chem. Chem. Eng. 2018, 37, 199-207.

80. Drzymalaa, J.; Kowalczuk, P.B.; Oteng-Peprah, M.; Foszcz, D.; Muszer, A.; Henc, T.; Luszczkiewicz, A. Application of the grade-recovery curve in the batch flotation of Polish copper ore. Miner. Eng. 2013, 49, 17-23. [CrossRef]

81. Uribe, L.; Gutierrez, L.; Jerez, O. The depressing effect of clay minerals on the floatability of chalcopyrite. Mineral. Process. Extr. Metall. Rev. 2016, 37, 227-235. [CrossRef]

82. Farokhpay, S. The significance of froth stability in mineral flotation -A review. Adv. Colloid Interface Sci. 2011, 166, 1-7. [CrossRef] [PubMed]

83. Yang, X.S.; Aldrich, C. Effects of impeller speed and aeration rate on flotation performance of sulphide ore. Trans. Nonferr. Met. Soc. China 2006, 16, 185-190. [CrossRef] 